\title{
Comparison of myocardial mechanical properties in patients with dilated cardiomyopathy with and without acute heart failure
}

\author{
Naila Choudhary*, Gangadhara Kabbli, Lynette J Duncanson, Michael Passick, Kathy Halloran, Jie J Cao \\ From 17th Annual SCMR Scientific Sessions \\ New Orleans, LA, USA. 16-19 January 2014
}

\section{Background}

Dilated cardiomyopathy (DCM) is characterized by impaired myocardial contractile function and/or diastolic relaxation in the setting of dilated left or both ventricles that ultimately leads to heart failure (HF). In this study, we aim to compare myocardial mechanical properties in DCM patients with and without acute HF.

\section{Methods}

We prospectively enrolled 20 patients with DCM and 8 normal controls. Of the 20 patients with DCM,
10 patients had acute HF, defined as B-type natriuretic peptide (BNP) greater than $400 \mathrm{pg} / \mathrm{ml}$, and the remaining 10 patients were determined to have no acute $\mathrm{HF}$ with BNP predominantly $<100 \mathrm{pg} / \mathrm{ml}$. All subjects underwent cardiac MRI using 1.5-T scanner. Left ventricular end-diastolic pressure (LVEDP) was assessed noninvasively using mean left atrial circulation transit time normalized by RR-interval during the first pass perfusion imaging. LV circumferential strain (CST) and strain rate (CSR) of mid LV in short axis plane and longitudinal strain (LST) and strain rate (LSR) in 4-chamber view

Table 1 Comparison of Strain and Strain Rate In Dilated Cardiomyopathy Patients With and Without Acute Heart Failure (HF)

\begin{tabular}{|c|c|c|c|c|}
\hline Mechanical Characteristics & Groups & Mean $\pm S D$ & $P$ value & Change (\%) \\
\hline CST (\%) & $\begin{array}{c}\text { Controls } \\
\text { No HF } \\
\text { HF }\end{array}$ & $\begin{array}{c}-14.6 \pm 3.4 \\
-9.4 \pm 2.7 \\
-5.2 \pm 1.8\end{array}$ & $<0.001$ & $\begin{array}{l}- \\
36 \\
65\end{array}$ \\
\hline CSR (\%/second) & $\begin{array}{c}\text { Controls } \\
\text { No HF } \\
\text { HF }\end{array}$ & $\begin{array}{l}-86.8 \pm 20.9 \\
-66.5 \pm 20.5 \\
-31.4 \pm 10.7\end{array}$ & $<0.001$ & $\begin{array}{l}- \\
23 \\
64\end{array}$ \\
\hline Rate of Circumferential Early Diastolic Relaxation (\%/second) & $\begin{array}{c}\text { Controls } \\
\text { No HF } \\
\text { HF }\end{array}$ & $\begin{array}{c}56.3 \pm 13.2 \\
27.2 \pm 9.6 \\
21.9 \pm 12.1\end{array}$ & $<0.001$ & $\begin{array}{l}- \\
52 \\
61\end{array}$ \\
\hline LST (\%) & $\begin{array}{c}\text { Controls } \\
\text { No HF } \\
\text { HF }\end{array}$ & $\begin{array}{c}-14.1 \pm 1.6 \\
-10.3 \pm 2.6 \\
-6.1 \pm 2.2\end{array}$ & $<0.001$ & $\begin{array}{c}- \\
27 \\
57\end{array}$ \\
\hline LSR (\%/second) & $\begin{array}{c}\text { Controls } \\
\text { No HF } \\
\text { HF }\end{array}$ & $\begin{array}{c}-65.9 \pm 9 \\
-58.5 \pm 11.9 \\
-29.8 \pm 11\end{array}$ & $<0.001$ & $\begin{array}{c}- \\
11 \\
55\end{array}$ \\
\hline Rate of Longitudinal Early Diastolic Relaxation (\%/second) & $\begin{array}{c}\text { Controls } \\
\text { No HF } \\
\text { HF }\end{array}$ & $\begin{array}{c}46 \pm 8 \\
26.7 \pm 13.4 \\
19.7 \pm 11.1\end{array}$ & $<0.001$ & $\begin{array}{l}- \\
42 \\
57\end{array}$ \\
\hline
\end{tabular}

CST: circumferential strain of mid left ventricle in short axis plane, CSR: circumferential strain rate of mid left ventricle in short axis plane, LST: longitudinal strain in 4-chamber view, LSR: longitudinal strain rate in 4-chamber view

Cardiology, Saint Francis Hospital, Roslyn, New York, USA 
were analyzed in cine images using feature tracking (CIM software, Auckland, New Zealand).

\section{Results}

LV ejection fraction (EF) was significantly reduced in acute HF and in no acute HF patients compared to normal controls; $22 \pm 7 \%, 39 \pm 9 \%$ and $55 \pm 2 \%$ respectively ( $\mathrm{p}<0.001$ ). Median BNP (range) was $885(1560) \mathrm{pg} / \mathrm{ml}$ in acute HF group, $26(266) \mathrm{pg} / \mathrm{ml}$ in no acute HF group and $15(48) \mathrm{pg} / \mathrm{ml}$ in normal controls $(\mathrm{p}<0.001)$. Estimated LVEDP was $22 \pm 12 \mathrm{mmHg}$ in acute $\mathrm{HF}$, $15 \pm 7 \mathrm{mmHg}$ in no acute $\mathrm{HF}$ and $8 \pm 2 \mathrm{mmHg}$ in normal controls $(\mathrm{p}=0.001)$. Using Pearson correlation, reduced CST, CSR, LST and LSR correlated highly with reduced EF; $r=-0.892,-0.790,-0.918,-0.890$ (all $\mathrm{p}<0.001)$. The magnitude of CST, CSR, LST and LSR reduction was similar to LVEF reduction: $29 \%$ in no acute $\mathrm{HF}$ and $59 \%$ in acute HF group using normal controls as reference (Table 1). In contrast, the reduction of relaxation rate in early diastole in no HF patients was nearly as great as in acute HF patients (Table 1).

\section{Conclusions}

CST, CSR, LST and LSR reduction were highly dependent on LVEF reduction suggesting load dependence of the indices. Despite marked differences in strain and strain rate reduction between patients with and without acute HF, the reduction of relaxation rate in early diastole was similarly high in both groups underscoring the significance of diastolic impairment in DCM patients which is relatively independent of HF status.

\section{Funding}

None.

Published: 16 January 2014

doi:10.1186/1532-429X-16-S1-P239

Cite this article as: Choudhary et al:: Comparison of myocardial mechanical properties in patients with dilated cardiomyopathy with and without acute heart failure. Journal of Cardiovascular Magnetic Resonance 2014 16(Suppl 1):P239.
Submit your next manuscript to BioMed Central and take full advantage of:

- Convenient online submission

- Thorough peer review

- No space constraints or color figure charges

- Immediate publication on acceptance

- Inclusion in PubMed, CAS, Scopus and Google Scholar

- Research which is freely available for redistribution

Submit your manuscript at www.biomedcentral.com/submit 